CASSOWARY Volume 2 (2): 193 - 208

ISSN : 2614-8900

E-ISSN : 2622-6545

CProgram Pascasarjana Universitas Papua, https://pasca.unipa.ac.id/

\title{
Pengaruh kepadatan kandang dan pembatasan ransum terhadap performans produksi dan tingkat cekaman pada Ayam Broiler
}

\author{
Effect of cage density and dietary restrictions on production performance and \\ stress levels in broiler chickens
}

Paskalis Robinson, Muh. Affan Mu'in, Irba Unggul Warsono*

Program Studi S2 Ilmu Peternakan, Program Pascasarjana Universitas Papua Jalan Gunung Salju, Amban, Manokwari, Kodepos 98314, Papua Barat, Indonesia.

*E-mail : irbauwar@gmail.com

\begin{abstract}
ABSRTACT: This study aims to determine the interaction between cage density with dietary restrictions on ration consumption, growth, feed conversion, carcass percentage, abdominal fat, heterophile-lymphocyte ratio and broiler chicken's Income Over Feed Cost. The research lasted for 2 months in the Cage of Broiler Chicken Farm SMK Negeri I Nabire. The research material used was 135 DOC unsex Cobb strain (CP 707) with an average weight of 42.5 grams / head; commercial feed starter BR1 CP 511 B and finisher BR2 CP 512 B and 27 units of battery cages. The experimental design used was a completely randomized design factorial pattern $(3 \times 3)$. Factor I is enclosure density with 3 levels, namely K1 (3 animals / $\left.0.5 \mathrm{~m}^{2}\right), \mathrm{K} 2\left(5\right.$ animals $\left./ 0.5 \mathrm{~m}^{2}\right)$ and $\mathrm{K} 3\left(7\right.$ animals $\left./ 0.5 \mathrm{~m}^{2}\right)$ and Factor II is restriction on ration with 3 levels namely R1 (100\% according to ad libitum requirements), R2 (85\%) and R3 (70\%) given at 4-5 weeks of age. Each treatment combination was repeated 3 times to obtain 27 experimental unit units. The results showed there was no interaction between cage density factors with dietary limitation factors for all observational variables. But the cage density factor, significantly $(\mathrm{P}<0.05)$ shows that the denser the cage the lower the consumption of rations and the percentage of abdominal fat in broilers. Whereas the restriction factor of the ration, significantly ( $\mathrm{P}$ $<0.05$ ) indicates that the higher the percentage of restriction ration the lower the ration consumed and the higher Income Over Feed Cost (the greater the business income of broiler chickens obtained) despite the indication of stress in broilers with a high average heterophyll-lymphocyte $(\mathrm{H} / \mathrm{L})$ ratio of 2.44 .
\end{abstract}

Keywords: Cage density, growth, feed conversion, broiler chicken.

ABSTRAK: Penelitian ini bertujuan untuk mengetahui interaksi antara kepadatan kandang dengan pembatasan ransum terhadap konsumsi ransum, pertumbuhan, konversi ransum, persentase karkas, lemak abdomen, ratio heterofil/limfosit dan Income Over Feed Cost ayam broiler. Penelitian berlangsung selama 2 bulan di Kandang Peternakan ayam broiler SMK Negeri I Nabire. Materi penelitian yang digunakan adalah 135 Day Old Chick (DOC) unsex strain cobb (CP 707) berat rata-rata 42,5 gram/ekor; pakan komersil starter BR1 CP 511 B dan finisher BR2 CP 512 B dan 27 unit kandang batere. Rancangan percobaan yang digunakan adalah Rancangan Acak Lengkap pola faktorial ( 3 x 3). Faktor I adalah kepadatan kandang dengan 3 level yaitu K1(3 ekor/0,5 m²),K2(5 ekor/0,5 $\left.\mathrm{m}^{2}\right)$ dan K3 (7 ekor/0,5 $\mathrm{m}^{2}$ ) dan Faktor II adalah Pembatasan ransum dengan 3 level yaitu R1 (100\% sesuai standar kebutuhan ad libitum ), R2 (85\%) dan R3 ( $70 \%$ ) 
yang diberikan pada umur 4-5 minggu. Setiap kombinasi perlakuan diulang 3 kali sehingga diperoleh 27 satuan unit percobaan. Hasil Penelitian menunjukkan tidak terdapat interaksi antara faktor kepadatan kandang dengan faktor pembatasan ransum terhadap semua variable pengamatan. Tetapi pada factor kepadatan kandang, secara signifikan $(\mathrm{P}<0,05)$ menunjukkan bahwa semakin padat kandang semakin menurunkan konsumsi ransum dan persentase lemak abdomen pada ayam broiler. Sedangkan pada faktor pembatasan ransum, secara signifikan $(\mathrm{P}<0,05)$ menunjukkan bahwa semakin tinggi persentase pembatasan ransum semakin rendah ransum yang dikonsumsi dan semakin tinggi Income Over Feed Cost (semakin besar pendapatan usaha ayam broiler yang diperoleh) meskipun terdapat indikasi cekaman atau stres pada ayam broiler dengan rataan ratio heterofil-limfosit (H/L) yang tinggi yaitu 2,44.

Kata kunci: Kepadatan kandang, pertumbuhan, konversi ransum, ayam broiler.

\section{PENDAHULUAN}

Ayam broiler memiliki waktu pemeliharaan yang singkat dan umumnya dipanen pada umur 4 - 5 minggu dengan bobot badan antara 1,2-1,9 kg/ekor serta sebagai sumber pedaging yang baik. Ayam broiler juga memiliki sifat karakteristik badan yang besar, berlemak, memiliki gerak yang lamban dan memiliki pertumbuhan yang cepat, serta menghasilkan daging dengan kandungan protein yang tinggi. Pemeliharaan ayam broiler di kalangan peternak biasanya kurang memperhatikan efek yang timbul sebagai akibat dari perubahan manajemen yang dilakukan. Penempatan ayam di dalam kandang sering hanya mempertimbangkan efisiensi tempat dan biaya kandang sehingga kepadatan untuk setiap ekor ayam kurang memadai untuk pertumbuhan normal. Kepadatan dan temperatur kandang berkaitan erat dengan tingkat kenyamanan bagi ayam dari tingkat efisiensi dan pemeliharaan. Indikator ketahanan tubuh sebagai bentuk respon ayam terhadap faktor-faktor penyebab cekaman dapat diketahui dari komponen darah seperti rasio heterofil/limfosit (H/L). Kusnadi (2008) menyatakan bahwa semakin tinggi angka rasio maka semakin tinggi pula tingkat cekaman sebagai bentuk stres pada unggas.

Banyak masalah yang cukup
serius dan sering muncul pada pemeliharaan ayam pedaging terutama di daerah tropis, seperti kematian pada akhir pemeliharaan, perlemakan yang banyak, dan kelainan pada kaki. Salah satu cara yang dapat dilakukan untuk mengatasi masalah tersebut adalah dengan pembatasan pakan, apakah dilakukan di awal pertumbuhan ataupun di masa akhir pertumbuhan (Aziz et al., 2011).

Pembatasan pemberian pakan bertujuan untuk mengurangi panas metabolik yang dihasilkan dari pakan yang dikonsumsi oleh ayam. Selain itu juga ayam broiler yang dibatasi pakannya menunjukkan efisiensi pakan yang lebih baik dan terjadi penurunan kandungan lemak tubuh yaitu lemak abdominal.

Lemak abdominal merupakan lemak tubuh yang disimpan dalam rongga perut termasuk lemak yang melindungi empedal (Essay dan Dawson, 1965). Energi yang berlebih akan disimpan dalam bentuk lemak dalam jaringanjaringan. Salah satu bagian tubuh yang digunakan untuk menyimpan lemak oleh ayam adalah bagian sekitar perut (abdomen).

Faktor lain yang harus diperhatikan pada pemeliharaan ayam 
broiler adalah biaya ransum. Biaya ransum merupakan biaya yang tertinggi dalam usaha peternakan ayam. Income over feed cost adalah pendapatan atas biaya ransum yang merupakan penerimaan usaha peternakan dibandingkan dengan biaya ransum. Penerimaan usaha merupakan perkalian antara hasil produksi peternakan dengan nilai atau harga pada saat itu (dalam kilogram hidup), sedangkan biaya ransum adalah jumlah biaya yang dikeluarkan untuk menghasilkan satu kilogram unggas hidup. Harapan peternak dalam memelihara ayam broiler adalah selain mendapatkan kandungan lemak rendah, persentase karkas yang tinggi, juga income over feed cost yang tinggi pula.

Tujuan penelitian adalah mengetahui interaksi antara kepadatan kandang dengan pembatasan ransum terhadap konsumsi ransum, pertumbuhan, konversi ransum, persentase karkas, lemak

\section{MATERI DAN METODE PENELITIAN}

Penelitian ini dilaksanakan selama 2 bulan di Kandang Peternakaan ayam broiler SMK Negeri I Nabire

Alat yang digunakan dalam penelitian ini adalah kandang kotak ukuran $0,7 \mathrm{mx} 0,7 \mathrm{~m}$ x $0,65 \mathrm{~m}$ sebanyak 27 buah, tempat pakan dan tempat minum gantung sebanyak masing-masing 27 buah, lampu pijar 100 watt sebagai pemanas 27 buah ditempatkan dalam unit percobaan, tiap unit terdapat 1 buah lampu dan 1 buah lampu penerang kandang, termometer dan termohygrometer untuk mengukur suhu dan kelembaban kandang, jarum venoject untuk mengambil darah ayam, tabung venoject untuk menampung sampel darah ayam,termos es untuk menyimpan tabung venoject yang telah terisi sampel darah, timbangan kapasitas $10 \mathrm{~kg}$ untuk menimbang pakan, bobot ayam, bobot abdomen, ratio heterofil/limfosit dan Income Over Feed Cost ayam broiler, mengetahui pengaruh kepadatan kandang terhadap konsumsi ransum, pertumbuhan, konversi ransum, persentase karkas, lemak abdomen, ratio heterofil/limfosit dan Income Over Feed Cost ayam broiler dan mengetahui pengaruh pembatasan ransum terhadap konsumsi ransum, pertumbuhan, konversi ransum, persentase karkas, lemak abdomen, ratio heterofil/limfosit dan Income Over Feed Cost ayam broiler.

Diharapkan hasil penelitian ini memberikan informasi yang bermanfaat bagi pengembangan ilmu pengetahuan dan teknologi tepat guna yang efesien dan efektif bagi produksi ayam broiler di bidang peternakan dan diharapkan sebagai bagian dari upaya pengembangan Ilmu Pengetahuan dan Teknologi yang berguna bagi Akademisi.

karkas serta timbangan digital untuk menimbang lemak abdominal, mikroskop, peralatan sanitasi kandang, peralatan bedah dan peralatan pengkarkasan.

Bahan yang digunakan dalam penelitian ini adalah Day Old Chick (DOC) unsex, strain cobb dengan merk dagang CP 707, sejumlah 135 ekor dengan kisaran bobot badan 40-45 gr dengan ratarata $42,5 \pm \mathrm{g}$. Ransum yang digunakan adalah ransum komersial starter BR1 CP 511 B dan finisher BR2 CP 512 B dari PT Charoen Pokphand Indonesia Tbk.

Penelitian eksperimen ini menggunakan Rancangan Acak Lengkap pola faktorial $(3 \times 3)$. Secara keseluruhan terdapat 9 kombinasi perlakuan dan setiap kombinasi perlakuan diulang sebanyak 3 kali sehingga diperoleh 27 satuan unit percobaan. Perlakuan yang diberikan terdiri dari 2 faktor, yaitu:

Faktor I : Kepadatan Kandang

$\mathrm{K} 1$ : Kepadatan kandang 3 ekor /0,5 $\mathrm{m}^{2}$ 
$\mathrm{K} 2$ : Kepadatan kandang 5 ekor $/ 0,5 \mathrm{~m}^{2}$

$\mathrm{K} 3$ : Kepadatan kandang 7 ekor $/ 0,5 \mathrm{~m}^{2}$ Faktor II : Pembatasan ransum pada umur 4-5 minggu

R1 : Pemberian ransum $100 \%$ sesuai standar kebutuhan diberikan secara ad libitum

R2 : Pemberian ransum $85 \%$ dari standar kebutuhan

R3 : Pemberian ransum $70 \%$ dari standar kebutuhan

Kombinasi perlakuan tingkat kepadatan kandang dan pembatasan ransum sebagai berikut :

Model matematis dari rancangan yang digunakan pada penelitian ini sebagai berikut:

$$
\begin{aligned}
& \text { Yijk }=\mu+K_{i}+R_{j}+(K R)_{i j}+\varepsilon_{i j k}: \\
& (i=1,2 \text {, dan } 3) \\
& (j=1,2 \text { dan } 3) \\
& (k=1,2 \text {, dan } 3)
\end{aligned}
$$

Keterangan :

$$
\begin{aligned}
& \text { Yijk = Respon akibat perlakuan } \\
& \mu \quad=\text { Nilai tengah umum } \\
& \mathrm{Ki}=\text { Pengaruh kepadatan kandang } \\
& \text { ke- i ( } i=1,2 \text {,dan 3) } \\
& \mathrm{Rj}=\text { Pengaruh pembatasan ransum } \\
& \text { ke-j }(\mathrm{j}=1,2 \text {,dan } 3) \\
& \mathrm{KR}_{\mathrm{ij}}=\text { Pengaruh interaksi kepadatan } \\
& \text { kandang ke-i dan pembatasan } \\
& \text { ransum ke-j } \\
& \varepsilon_{\mathrm{ijk}}=\text { Pengaruh galat percobaan }
\end{aligned}
$$

\section{HASIL DAN PEMBAHASAN}

\section{Pengaruh Perlakuan terhadap Konsumsi Ransum}

Rataan konsumsi ransum Ayam broiler pada perlakuan kepadatan kandang dan pembatasan ransum disajikan pada Tabel 1.
Kandang yang digunakan selama penelitian adalah kandang postal sistem litter dengan ukuran P X L yaitu 15 X 6 $\mathrm{m}$, didalamnya ditempatkan petak-petak kecil kandang terbuat dari kayu sebanyak 27 petak. Masing-masing petak dilengkapi alas kandang (litter) dari serutan kayu setebal $\pm 5 \mathrm{~cm}$ dan dilengkapi tempat pakan dan tempat minum yang diletakkan pada setiap petak perlakuan.

Penelitian ini menggunakan DOC ayam pedaging (broiler) sebanyak 135 ekor atau DOC unsex, strain Cobb dengan merk dagang CP 707 dengan rata-rata bobot badan $\pm 45 \mathrm{~g}$ dan dipelihara selama 35 hari. Fase pemeliharaan dibagi menjadi dua, yaitu fase starter umur 0-3 minggu (21 hari) dan fase finisher 4- 5 minggu. Ransum diberikan secara ad libitum (100\%) semenjak ayam berumur 0-3 minggu, sesuai standar kebutuhan berdasarkan tingkat pertumbuhan ayam. Sedangkan perlakuan pembatasan ransum dilakukan pada umur 4-5 minggu.

Variabel yang diamati adalah Konsumsi Ransum, Pertambahan Bobot Badan, Konversi Ransum, Persentase Karkas, Persentase lemak abdominal, Ratio heterofil/limfosit (H/L) dan Income Over Feed Cost (IOFC)

Data yang diperoleh dilakukan analisis variansi sesuai prosedur rancangan yang digunakan. Bila hasil menunjukkan adanya pengaruh perlakuan, analisis dilanjutkan dengan Uji Tukey pada tingkat significant $5 \%$. 
Tabel 1. Rataan Konsumsi Ransum pada perlakuan Kepadatan Kandang dan Pembatasan Ransum (g/ekor)

\begin{tabular}{|c|c|c|c|c|}
\hline \multirow{2}{*}{$\begin{array}{l}\text { Kepadatan } \\
\text { Kandang } \\
\left(\text { ekor } / 0,5 \mathrm{~m}^{2} \text { ) }\right.\end{array}$} & \multicolumn{3}{|c|}{ Pembatasan Ransum (\% dari kebutuhan) } & Rataan \\
\hline & $\mathrm{R}_{1}(100 \%)$ & $\mathrm{R}_{2}(85 \%)$ & $\mathrm{R}_{3}(70 \%)$ & \\
\hline $\mathrm{K}_{1}$ (3 ekor) & $2414.11 \pm 41.7$ & $2218.22 \pm 11.4$ & $1980.33 \pm 16.5$ & $2204.22^{a} \pm 189.5$ \\
\hline $\mathrm{K}_{2}(5$ ekor $)$ & $2397.93 \pm 37.9$ & $2163.53 \pm 61.1$ & $1999.60 \pm 2.03$ & $2187.02^{\mathrm{ab}} \pm 177.1$ \\
\hline $\mathrm{K}_{3}$ (7 ekor) & $2383.86 \pm 47.7$ & $2080.38 \pm 84.3$ & $1987.66 \pm 20.79$ & $2150.63^{b} \pm 186.2$ \\
\hline Rataan & $\begin{array}{c}2398.63^{\mathrm{a}} \\
\pm 39.2\end{array}$ & $\begin{array}{c}2154.04^{\mathrm{b}} \\
\pm 79.7\end{array}$ & $\begin{array}{c}1989.20^{\mathrm{c}} \\
\pm 15.8\end{array}$ & 2180.62 \\
\hline
\end{tabular}

Superskrip yang berbeda dalam satu baris rataan atau satu kolom rataan menunjukkan terdapat perbedaan yang nyata $(\mathrm{P}<0,05)$

Tabel 1 memperlihatkan bahwa rataan konsumsi ransum pada penelitian ini berkisar antara $1980.33 \pm 16.5$ g/ekor sampai dengan 2414.11 41.7 g/ekor. Menurut Pedoman Standard Technical Service PT Charoen Pokphand (2006), standar konsumsi pakan untuk strain $\mathrm{CP}$ 707 adalah 2437 g/ekor selama minggu ke tiga sampai minggu ke lima pemeliharaan. Hasil penelitian menunjukkan lebih rendah dari standar konsumsi ransum menurut Pedoman Standard Technical Service PT Charoen Pokphand. Lebih rendahnya konsumsi ransum hasil penelitian ini diduga karena adanya perlakuan

Hasil analisis ragam menunjukkan bahwa tidak ada pengaruh interaksi kepadatan kandang dan pembatasan ransum $(\mathrm{P}>0,05)$ terhadap konsumsi ransum, tetapi faktor perlakuan kepadatan kandang dan faktor pembatasan ransum memberikan pengaruh nyata $(\mathrm{P}<0,05)$ terhadap konsumsi ransum. Tidak adanya interaksi ini dapat mengindikasikan bahwa kedua faktor tersebut adalah faktor yang bebas sama sekali tidak saling tergantung. Hal ini menunjukkan bahwa faktor kepadatan kandang dan faktor pembatasan ransum saling menekan pengaruh masing-masing sehingga interaksinya dapat bersifat negatif bila diterapkan secara bersama.

Hasil uji Tukey menunjukkan bahwa faktor kepadatan kandang pada perlakuan $\mathrm{K} 1\left(3 \mathrm{ekor} / 0,5 \mathrm{~m}^{2}\right)$ konsumsi ransumnya (2204.22 g/ekor) secara nyata $(\mathrm{K}<0,05)$ lebih tinggi dibanding konsumsi ransum pada perlakuan $\mathrm{K} 2$ (5 ekor/0,5 $\mathrm{m}^{2}$ ) yaitu 2187.02 g/ekor dan K3 (7 ekor/0,5 $\mathrm{m}^{2}$ ) sebesar 2150.63 g/ekor. Sedangkan konsumsi ransum pada perlakuan antara K2 dengan K3 tidak menunjukkan perbedaan yang nyata $(\mathrm{P}>0,05)$. Tingginya konsumsi ransum pada tingkat kepadatan 3 ekor/0,5 $\mathrm{m}^{2} \quad$ (K1) dibandingkan konsumsi ransum, baik pada tingkat kepadatan 5 ekor/0,5 $\mathrm{m}^{2}$ ) maupun pada tingkat kepadatan 7 ekor/0,5 $\mathrm{m}^{2}$ (K3), hal ini diduga karena kondisi suhu kandang yang optimal tanpa terjadinya cekaman sehingga ayam merasa nyaman untuk mengkonsumsi ransum yang tersedia. Hal ini sesuai pendapat Rasyaf (2011), bahwa kepadatan kandang optimal untuk ternak ayam dipengaruhi oleh suhu kandang. Semakin tinggi suhu udara dalam kandang maka kepadatan kandang optimal semakin rendah dan sebaliknya semakin rendah suhu udara dalam kandang, maka 
kepadatan kandang optimal semakin tinggi.

Perlakuan pembatasan ransum memberikan perbedaan nyata pada setiap taraf perlakuannya $(\mathrm{P}<0,05)$. Adanya perbedaan ini disebabkan karena jumlah ransum yang terbatas yang dikonsumsi pada perlakuan R2 (85\%) dan R3 (70\%). Sehingga terbatasnya penyediaan pakan akan mengurangi kesempatan ayam broiler untuk makan. Semakin terbatas penyediaan pakan, kesempatan itu berkurang sehingga konsumsi pakan juga berkurang. Penyediaan pakan secara ad-

\section{Pengaruh Perlakuan terhadap Pertambahan Bobot Badan}

Rataan Pertambahan bobot badan ayam broiler pada perlakuan kepadatan kandang dan libitum (100\%) akan memberikan kesempatan ayam untuk mengkonsumsi pakan setiap saat sesuai dengan kebutuhannya. Sejalan dengan pendapat Amrullah (2004) yang menyatakan bahwa ayam broiler memiliki kecenderungan untuk makan lebih banyak jika ada kesempatan makan seperti pada pemberian pakan secara ad-libitum yaitu perlakuan R1 (100\%) dan konsumsi pakan akan berkurang jika waktu pemberian pakan dibatasi, berkurangnya konsumsi pakan sejalan dengan lamanya pembatasan pemberian pakan.

pembatasan ransum disajikan pada Tabel 2.

Tabel 2. Rataan Pertambahan Bobot Badan ayam broiler pada perlakuan Kepadatan Kandang dan Pembatasan Ransum (g/ekor/minggu)

\begin{tabular}{lcccc}
\hline \hline \multirow{2}{*}{$\begin{array}{l}\text { Kepadatan Kandang } \\
(\text { ekor/0,5m })\end{array}$} & \multicolumn{3}{c}{ Pembatasan Ransum (\% dari kebutuhan) } & \multirow{2}{*}{ Rataan } \\
\cline { 2 - 4 } & $\mathrm{R}_{1}(100 \%)$ & $\mathrm{R}_{2}(85 \%)$ & $\mathrm{R}_{3}(70 \%)$ & $288^{\mathrm{a}}$ \\
\hline $\mathrm{K}_{1}(3$ ekor) & $293 \pm 32.10$ & $305 \pm 19.11$ & $267 \pm 20.95$ & \pm 27.19 \\
$\mathrm{~K}_{2}$ (5 ekor) & & & & $265^{\mathrm{a}}$ \\
& $283,32 \pm 5.25$ & $252,44 \pm 25.92$ & $260 \pm 38.99$ & \pm 27.40 \\
$\mathrm{~K}_{3}$ (7 ekor) & & & & $264^{\mathrm{a}}$ \\
& $275,03 \pm 17.11$ & $261,26 \pm 18.16$ & $257,09 \pm 9.96$ & \pm 15.71 \\
\hline Rataan & $283,78^{\mathrm{a}} \pm$ & $272,9^{\mathrm{a}} \pm 30.5$ & $261,36^{\mathrm{a}} \pm 23.12$ & 272,33
\end{tabular}

Superskrip yang sama dalam satu baris rataan atau satu kolom rataan menunjukkan tidak terdapat perbedaan yang nyata $(\mathrm{P}>0,05)$

Tabel 2 memperlihatkan bahwa rataan pertambahan bobot badan mingguan ayam broiler pada perlakuan kepadatan kandang dengan pembatasan ransum berkisar antara 257,09 \pm 9.96 g/ekor/mgg - 305 $\pm 19.11 \mathrm{~g} / \mathrm{ekor} / \mathrm{mgg}$.
Hasil analisis ragam menunjukkan tidak ada pengaruh interaksi kepadatan kandang dengan pembatasan ransum $(\mathrm{P}>0,05)$ terhadap pertambahan bobot badan ayam broiler. Tidak adanya pengaruh interaksi antara kepadatan kandang dan pembatasan ransum 
terhadap pertambahan bobot badan diduga kurang maksimalnya konsumsi ransum akibat pembatasan ransum dan tingkat kepadatan kandang yang berbeda sehingga menyebabkan suplai nutrisi dan energi berkurang dan terjadinya cekaman. Jika hal ini terjadi maka akan berakibat pada pertambahan bobot badan yang dicapai tidak maksimal pula. Faktorfaktor yang menyebabkan tidak terjadinya pertambahan bobot badan selama periode pembatasan pemberian ransum antara lain dikarenakan terbatasnya suplai nutrisi dan energi untuk menunjang pertumbuhan jaringan (Hornick et al., 2000. Kepadatan

\section{Pengaruh Perlakuan terhadap Konversi Ransum}

Rataan Konversi Ransum ayam broiler pada perlakuan kepadatan

Tabel 3. Rataan Konversi Ransum ayam broiler pada perlakuan Kepadatan Kandang dan Pembatasan Ransum

\begin{tabular}{lcccc}
\hline \hline \multirow{2}{*}{$\begin{array}{l}\text { Kepadatan } \\
\text { Kandang }\end{array}$} & \multicolumn{3}{c}{ Pembatasan Ransum (\% dari kebutuhan) } & \multirow{2}{*}{ Rataan } \\
\cline { 2 - 4 } & $\mathrm{R}_{1}(100 \%)$ & $\mathrm{R}_{2}(85 \%)$ & $\mathrm{R}_{3}(70 \%)$ & \\
\hline $\mathrm{K}_{1}(3$ ekor $)$ & $1,65 \pm 0.14$ & $1,45 \pm 0.09$ & $1,49 \pm 0.12$ & $1,53^{\mathrm{a}} \pm 0.13$ \\
$\mathrm{~K}_{2}(5$ ekor $)$ & $1,68 \pm 0.05$ & $1,71 \pm 0.12$ & $1,56 \pm 0.26$ & $1,65^{\mathrm{a}} \pm 0.16$ \\
$\mathrm{~K}_{3}(7$ ekor $)$ & $1,67 \pm 0.005$ & $1,59 \pm 0.13$ & $1,63 \pm 0.20$ & $1,63^{\mathrm{a}} \pm 0.12$ \\
\hline Rataan & $1,67^{\mathrm{a}} \pm 0.07$ & $1,58^{\mathrm{a}} \pm 0.15$ & $1,56^{\mathrm{a}} \pm 0.18$ & 1,60
\end{tabular}

Superskrip yang sama dalam satu baris rataan atau satu kolom rataan menunjukkan tidak terdapat perbedaan yang nyata $(\mathrm{P}>0,05)$

Tabel 3 memperlihatkan bahwa rataan konversi ransum hasil penelitian dari perlakuan kepadatan kandang dengan pembatasan ransum bersisar antara $1,45 \pm 0.09$ - 1,71 \pm 0.12 , selama lima minggu pemeliharaan.

Hasil analisis ragam menunjukkan tidak terdapat adanya pengaruh interaksi kepadatan kandang dengan pembatasan ransum $\quad(\mathrm{P}>0,05)$ terhadap konversi ransum ayam broiler. Hal ini berarti bahwa tidak terdapat adanya interaksi perlakuan kepadatan kandang dengan kandang yang tidak berbeda nyata $(\mathrm{P}>0,05)$ terhadap pertambahan bobot badan, diduga karena faktor cekaman pada ayam pedaging yang disebabkan oleh kurangnya sirkulasi udara dan semakin tingginya kadar amoniak seiring bertambahnya kepadatan kandang, sehingga menyebabkan terjadinya heat increament yang mempengaruhi kemampuan ayam pedaging untuk melakukan metabolisme zat makanan dari bahan pakan yang telah dikonsumsi yang pada akhirnya berpengaruh terhadap pertambahan bobot badan ayam pedaging.

kandang dan pembatasan ransum disajikan pada Tabel 3 . 
$\mathrm{R}_{2}(85 \%)$ dan konversi ransum tertinggi pada kombinasi perlakuan kepadatan kandang $\mathrm{K}_{2} \quad\left(5\right.$ ekor/0,5 $\left.\mathrm{m}^{2}\right)$ dengan pembatasan ransum $\mathrm{R}_{2}(85 \%)$ yaitu 1,71 \pm 0.12 . Pada Tabel 3 juga menunjukkan bahwa nilai konversi ransum pada kelompok ayam yang mendapat pembatasan ransum hingga $70 \%$ dari kebutuhan, cenderung lebih baik dibandingkan dengan ayam yang diberi

\section{Pengaruh Perlakuan terhadap Persentase Karkas}

Rataan persentase karkas ayam broiler pada perlakuan kepadatan kandang ransum secara ad-libitum (100\%). Sebaliknya pada perlakuan kepadatan kandang 7 ekor/0,5 $\mathrm{m}^{2}$ nilai konversi ransum relatif sama dengan konversi pakan pada tingkat kepadatan 5 ekor/0,5 $\mathrm{m}^{2}$. Faktor-faktor yang mempengaruhi konversi ransum antara lain genetik, tempratur, ventilasi, kualitas pakan, jenis ransum, penyakit serta manajemen pemeliharaan.

dan pembatasan ransum disajikan pada Tabel 4.

Tabel 4. Rataan persentase Karkas ayam broiler pada perlakuan Kepadatan Kandang dan Pembatasan Ransum (\%).

\begin{tabular}{lcccc}
\hline \hline Kepadatan & \multicolumn{3}{c}{ Pembatasan Ransum (\% dari kebutuhan) } & \\
\cline { 2 - 3 } Kandang (ekor/0.5 & & & Rataan \\
$\left.\mathrm{m}^{2}\right)$ & $\mathrm{R}_{1}(100 \%)$ & $\mathrm{R}_{2}(85 \%)$ & $\mathrm{R}_{3}(70 \%)$ & \\
\hline $\mathrm{K}_{1}$ (3 ekor) & & & & $69,13^{\mathrm{a}} \pm$ \\
& $69,39 \pm 3.90$ & $69,42 \pm 2.28$ & $68,59 \pm 0.17$ & 2.32 \\
$\mathrm{~K}_{2}(5$ ekor) & & & & $69,54^{\mathrm{a}} \pm$ \\
& $69,30 \pm 2.23$ & $69,32 \pm 2.57$ & $70,01 \pm 3.20$ & 2.36 \\
$\mathrm{~K}_{3}(7$ ekor) & & & & $69,19^{\mathrm{a}} \pm$ \\
& $69,55 \pm 2.80$ & $70,3 \pm 1.36$ & $67,72 \pm 0.99$ & 1.99 \\
\hline Rataan & $69,41^{\mathrm{a}} \pm 2.65$ & $69,68^{\mathrm{a}} \pm 1.91$ & $68,77^{\mathrm{a}} \pm 1.98$ & 69,28
\end{tabular}

Superskrip yang sama dalam satu baris rataan atau satu kolom rataan menunjukkan tidak terdapat perbedaan yang nyata $(\mathrm{P}<0,05)$

Tabel 4 memperlihatkan bahwa rataan persentase karkas ayam broiler hasil penelitian dari perlakuan kepadatan kandang dengan perlakuan pembatasan ransum berkisar antara $67,72 \% \pm 0.99$ $70,3 \% \pm 1.36$. Persentase Karkas paling rendah tersebut terdapat pada kombinasi perlakuan kepadatan kandang 7 ekor/0,5 $\mathrm{m}^{2}$ dengan pembatasan ransum $70 \%$ dan persentase karkas tertinggi terdapat pada kombinasi perlakuan antara kepadatan kandang 7 ekor/ $/, 5 \mathrm{~m}^{2}$ dengan pembatasan ransum $85 \%$.

Hasil analisis ragam menunjukkan tidak ada pengaruh interaksi kepadatan kandang dengan pembatasan ransum $(\mathrm{P}>0,05)$ terhadap persentase karkas. Menurut Al-Batshan, (2002) kepadatan kandang yang tinggi menyebabkan peningkatan temperatur kandang yang disebabkan oleh panas yang dihasilkan ayam dari proses metabolisme. Hal ini 
menyebabkan meningkatnya suhu tubuh pada ayam pedaging yang ditandai dengan menurunnya konsumsi pakan dan pertambahan bobot badan. Selanjutnya menurut Hamidi (2006) bahwa pada saat ayam mengalami stres panas, maka ayam

\section{Pengaruh Perlakuan terhadap Persentase Lemak Abdominal}

Rataan persentase lemak abdominal ayam broiler pada perlakuan kepadatan kandang dan pembatasan ransum disajikan pada Tabel 5. akan menurunkan konsumsi pakan sehingga mengakibatkan pencapaian bobot badan akhir tidak maksimal, sehingga mempengaruhi pencapaian persentase karkas yang tidak maksimal.

Tabel 5. Rataan Persentase Lemak Abdominal ayam broiler pada perlakuan Kepadatan Kandang dan Pembatasan Ransum (\%).

\begin{tabular}{lcccc}
\hline Kepadatan & \multicolumn{2}{c}{ Pembatasan Ransum (\% dari kebutuhan) } & \\
\cline { 2 - 4 } Kandang (ekor/0.5 & & & Rataan \\
$\left.\mathrm{m}^{2}\right)$ & $\mathrm{R}_{1}(100 \%)$ & $\mathrm{R}_{2}(85 \%)$ & $\mathrm{R}_{3}(70 \%)$ & \\
\hline $\mathrm{K}_{1}(3$ ekor) & $2,09 \pm 0.02$ & $1,67 \pm 0.16$ & $1,9 \pm 0.07$ & $1,88^{\mathrm{a}} \pm 0.31$ \\
$\mathrm{~K}_{2}(5$ ekor) & $1,61 \pm 0.10$ & $1,4 \pm 0.18$ & $1,33 \pm 0.46$ & $1,44^{\mathrm{b}} \pm 0.22$ \\
$\mathrm{~K}_{3}(7$ ekor $)$ & $1,75 \pm 0.49$ & $1,49 \pm 0.28$ & $1,68 \pm 0.17$ & $1,64^{\mathrm{b}} \pm 0.27$ \\
\hline Rataan & $1,82^{\mathrm{a}} \pm 0.23$ & $1,52^{\mathrm{b}} \pm 0.28$ & $1,63^{\mathrm{ab}} \pm 0.39$ & 1,66 \\
\hline
\end{tabular}

Superskrip yang berbeda dalam satu baris rataan atau satu kolom rataan menunjukkan terdapat perbedaan yang nyata $(\mathrm{P}<0,05)$

Tabel 5 memperlihatkan rataan persentase lemak abdomen dari perlakuan kepadatan kandang dengan pembatasan ransum yaitu antara $1,33 \% \pm 0.46$ $2,09 \% \pm 0.02$. Persentase lemak abdomen paling rendah terdapat pada kombinasi perlakuan kepadatan kandang 5 ekor $/ 0,5 \mathrm{~m}^{2}$ dengan pembatasan ransum $70 \%$ dan persentase lemak abdomen tertinggi terdapat pada kombinasi perlakuan antara kepadatan kandang 3 ekor $/ 0,5 \mathrm{~m}^{2}$ dengan tanpa pembatasan ransum $(100 \%)$.

Hal ini diduga karena pada perlakuan kepadatan kandang 3 ekor ayam tidak mengalami cekaman sehingga berpengaruh terhadap pertumbuhan dan mengakibatkan peningkatan deposisi lemak abdominal. Kemudian di kombinasi dengan perlakuan tanpa pembatasan ransum dimana pada pemberian ransum $100 \%$ (berdasarkan standar kebutuhan) maka kebutuhan energi yang diperoleh dalam ransum yang dikonsumsi ayam broiler terpenuhi sehingga akan berpeluang untuk terjadinya peningkatan lemak abdominal. Namun rataan persentase lemak abdominal berdasarkan hasil penelitian ini masih dalam kisaran normal. Menurut Becker et al (1979), persentase lemak abdominal ayam broiler berkisar antara $0,73 \%$ sampai $3,78 \%$.

Hasil analisis ragam menunjukkan bahwa tidak terdapat pengaruh interaksi kepadatan kandang dengan pembatasan ransum $(\mathrm{P}>0,05)$ terhadap persentase 
lemak abdominal. Tetapi faktor kepadatan kandang dan faktor pembatasan ransunsum masing-masing memberikan pengaruh yang nyata $(\mathrm{P}<0,05)$ terhadap persentase lemak abdominal. Hasil uji Tukey pada faktor kepadatan kandang menunjukkan bahwa perlakuan kepadatan kandang $\mathrm{K} 1$ ( 3 ekor/0,5 $\mathrm{m}^{2}$ ) berbeda nyata $(\mathrm{P}<0,05)$ dengan perlakuan kepadatan kandang $\mathrm{K}_{2}\left(5\right.$ ekor $\left./ 0,5 \mathrm{~m}^{2}\right)$ dan $\mathrm{K}_{3}$ (5 ekor/0,5 $\left.\mathrm{m}^{2}\right)$ tetapi antara $\mathrm{K}_{2}(5$ ekor/0,5 $\left.\mathrm{m}^{2}\right)$ dan $\mathrm{K}_{3}\left(5 \mathrm{ekor} / 0,5 \mathrm{~m}^{2}\right)$ tidak menunjukkan adanya perbedaan yang nyata $(\mathrm{P}>0,5)$. Sedangkan hasil análisis uji Turkey pada faktor pembatasan ransum menunjukkan bahwa persentase lemak abdominal pada pembatasan ransum level $\mathrm{R}_{2}(85 \%)$ secara nyata $(\mathrm{P}<0,05)$ lebih rendah dibanding pada level $\mathrm{R}_{1}(100 \%)$ tetapi tidak berbeda nyata $(\mathrm{P}>0,05)$ dengan level $\mathrm{R}_{3}(70 \%)$ dan antara level $\mathrm{R}_{1}$ dan $R_{3}$ juga tidak terdapat perbedaan yang nyata $(\mathrm{P}>0,05)$.

Hal ini diduga semakin padat kandang meningkatnya suhu kandang akibat panas yg dihasilkan oleh tubuh ayam sehingga tidak terjadi penimbunan lemak abdomen yg berlebihan. Hal ini sesuai pendapat Gaman (1992), perlemakan tubuh diakibatkan dari konsumsi energi yang berlebih yang akan disimpan dalam jaringan tubuh yaitu pada bagian intramuscular, subkutan dan abdominal. Kelebihan energi pada ayam akan menghasilkan karkas yang mengandung lemak lebih tinggi dan rendahnya konsumsi menyebabkan lemak dan karbohidrat yang disimpan dalam glikogen rendah.

\section{Pengaruh Perlakuan terhadap rasio Heterofil-Limfosit (H/L)}

Rataan rasio heterofil-limfosit

(H/L) ayam broiler pada perlakuan kepadatan kandang dan pembatasan ransum disajikan pada Tabel 6 .

Tabel 6. Rataan rasio Heterofil-Limfosit (H/L) ayam broiler pada perlakuan Pengaruh Kepadatan Kandang dan Pembatasan ransum

\begin{tabular}{|c|c|c|c|c|}
\hline \multirow{2}{*}{$\begin{array}{l}\text { Kepadatan } \\
\text { Kandang } \\
\left(\text { ekor } / 0,5 \mathrm{~m}^{2} \text { ) }\right.\end{array}$} & \multicolumn{3}{|c|}{ Pembatasan Ransum (\% dari kebutuhan) } & \multirow{2}{*}{ Rataan } \\
\hline & $\mathrm{R}_{1}(100 \%)$ & $\mathrm{R}_{2}(85 \%)$ & $\mathrm{R}_{3}(70 \%)$ & \\
\hline $\mathrm{K}_{1}$ (3 ekor) & $4,14 \pm 0.82$ & $2,12 \pm 0.48$ & $2,35 \pm 1.75$ & $2,87^{\mathrm{a}} \pm 1.38$ \\
\hline $\mathrm{K}_{2}$ (5 ekor) & $2,60 \pm 1.93$ & $1,88 \pm 2.21$ & $3,99 \pm 2.96$ & $2,82^{\mathrm{a}} \pm 2.28$ \\
\hline $\mathrm{K}_{3}$ (7 ekor) & $3,16 \pm 2.95$ & $1,20 \pm 0.61$ & $0,56 \pm 0.16$ & $1,64^{\mathrm{a}} \pm 1.91$ \\
\hline Rataan & $\begin{array}{c}3,30^{\mathrm{a}} \pm \\
1.93\end{array}$ & $1.73^{\mathrm{a}} \pm 1.73$ & $2.3^{\mathrm{a}} \pm 2.27$ & 2,44 \\
\hline
\end{tabular}

Superskrip yang sama dalam satu baris rataan atau satu koolom rataan menunjukkan tidak terdapat perbedaan yang nyata $(\mathrm{P}<0,05)$

Tabel 6 memperlihatkan bahwa rataan rasio heterofil-limfosit $(\mathrm{H} / \mathrm{L})$ dari perlakuan kepadatan kandang dengan pembatasan ransum yaitu antara
$0,56 \pm 0.16-4,14 \pm 0.82$. rasio heterofillimfosit (H/L) paling rendah terdapat pada kombinasi perlakuan kepadatan kandang 7 ekor/0,5 $\mathrm{m}^{2}$ dengan pembatasan ransum 
$70 \%$ dan rasio heterofil-limfosit (H/L) tertinggi terdapat pada kombinasi perlakuan antara kepadatan kandang 3 ekor $/ 0,5 \mathrm{~m}^{2}$ dengan tanpa pembatasan ransum $(100 \%)$.

- Hasil ini penelitian ini menunjukkan lebih tinggi dibandingkan menurut Emadi dan Kermanshahi (2007), dimana tingkat ketahanan tubuh pada unggas dapat ditentukan oleh nilai rasio heterofil-limfosit $(\mathrm{H} / \mathrm{L})$; sekitar 0,2 (randah), 0,5 (normal) dan 0,8 (tinggi) terhadap adaptasi lingkungan. Tingginya perbedaan nilai rasio heterofil-limfosit (H/L) tersebut diduga dipengaruhi oleh perbedaan pola pemeliharan terutama faktor perlakuan penelitian yaitu faktor kepadatan kandang dan pembatasan ransum. Faktor pembatasan ransum yang diikuti dengan tingkat kepadatan yang berbeda memicu timbulnya cekaman stress yang mengakibatkan jumlah heterofil lebih tinggi dibandingkan jumlah limfosit. Heterofil adalah sistem pertahanan pertama dari serangan benda asing dalam tubuh. Sedangkan fungsi utama limfosit adalah merespon adanya antigen (benda-benda asing) dengan membentuk antibodi yang bersirkulasi di

\section{Pengaruh Perlakuan terhadap Income Over Feed Cost (IOFC)}

Rataan Income Over Feed Cost (IOFC) ayam broiler pada perlakuan kepadatan kandang dan pembatasan ransum disajikan pada Tabel 7 . dalam darah atau dalam pengembangan imunitas atau kekebalan seluler (Tizard, 1987). Heterofil dengan nilai tinggi tidak selalu menunjukkan ayam dalam kondisi cekaman, namun bisa juga berfungsi dalam proses fagositosis.

Hasil analisis ragam menunjukkan bahwa tidak ada pengaruh interaksi kepadatan kandang dengan pembatasan ransum $(\mathrm{P}>0,05)$ terhadap ratio heterofillimfosit (H/L). Hasil uji Tukey menunjukkan tidak adanya perbedaan yang nyata $(\mathrm{P}>0,05)$ antara setiap perlakuan. Hal ini berarti bahwa meskipun terdapat adanya indikasi adanya stres atau cekaman pada ayam broiler dengan tingginya nilai rasio heterofil-limfosit (H/L) akibat faktor perlakuann namun masih mampu menunjukkan performans produksi yang relatif sama dengan yang mendapat perlakuan kombinasi antara tanpa pembatasan ransum $\mathrm{R}_{1}(100 \%)$ dengan kepadatan kandang yang normal 5 ekor/0,5 m2 $\left(\mathrm{K}_{2}\right)$. Ratio heterofil-limfosit merupakan indikator stres akibat cekaman pada ayam broiler yang mudah diketahui. Semakin tinggi angka rasio maka semakin tinggi pula cekaman sebagai bentuk stres pada unggas (Kusnadi, 2009).

Tabel 7. Rataan Income Over Feed Cost (IOFC) ayam broiler pada perlakuan Kepadatan Kandang dan Pembatasan Ransum (Rp/ekor)

\begin{tabular}{lcccc}
\hline \hline \multirow{2}{*}{$\begin{array}{l}\text { Kepadatan } \\
\text { Kandang } \\
(\text { ekor/0,5 }\end{array}$} & \multicolumn{2}{c}{ Pembatasan Ransum $)$} & \multirow{2}{*}{ Rataan } \\
\cline { 2 - 4 } & $\mathrm{R}_{1}(100 \%)$ & $\mathrm{R}_{2}(85 \%)$ & $\mathrm{R}_{3}(70 \%)$ & \\
\hline $\mathrm{K}_{1}(3$ ekor $)$ & $8,560 \pm 1857.41$ & $10,309 \pm 1922.14$ & $15,455 \pm 5040.04$ & $11,442^{\mathrm{a}} \pm 4.22$ \\
$\mathrm{~K}_{2}(5$ ekor $)$ & $10,490 \pm 2276.57$ & $16,949 \pm 6101.48$ & $14,414 \pm 1969.47$ & $13,951^{\mathrm{a}} \pm 4.42$ \\
$\mathrm{~K}_{3}(7$ ekor $)$ & $11,063 \pm 2070.23$ & $13,965 \pm 1343.19$ & $15,557 \pm 3029.85$ & $13,528^{\mathrm{a}} \pm 2.77$ \\
\hline Rataan & $10,038^{\mathrm{b}} \pm 2.12$ & $13,741^{\mathrm{ab}} \pm 4.36$ & $15,142^{\mathrm{a}} \pm 3.15$ & 12,974 \\
\hline
\end{tabular}


Superskrip yang berbeda dalam satu baris rataan atau satu kolom rataan menunjukkan terdapat perbedaan yang nyata $(\mathrm{P}<0,05)$

Tabel 7 memperlihatkan rataan Income Over Feed Cost dari perlakuan kepadatan kandang dengan pembatasan ransum yaitu antara Rp. 8,560 $\pm 1857.41-$ Rp. 16,949 \pm 6101.48 . Rataan Income Over Feed Cost (IOFC) ayam broiler paling rendah terdapat pada kombinasi perlakuan kepadatan kandang 3 ekor/ $0,5 \mathrm{~m}^{2}$ dengan pembatasan ransum $100 \%$ atau tanpa pembatasan ransum dan rataan Income Over Feed Cost (IOFC) ayam broiler tertinggi terdapat pada kombinasi perlakuan antara kepadatan kandang 5 ekor/0,5 $\mathrm{m}^{2}$ dengan a pembatasan ransum $85 \%$.

Hasil analisis ragam menunjukkan tidak ada pengaruh interaksi kepadatan kandang dengan pembatasan ransum $(\mathrm{P}>0,05)$ terhadap Income Over Feed Cost (IOFC), tetapi perlakuan pembatasan ransum memberikan pengaruh nyata $(\mathrm{P}<0,05)$ terhadap Income Over Feed Cost (IOFC). Sedangkan perlakuan tingkat kepadatan kandang tidak memberikan pengaruh nyata $(\mathrm{P}>0,05)$ terhadap Income Over Feed Cost (IOFC).

Hasil uji Tukey menunjukkan perlakuan pembatasan ransum $\left(\mathrm{R}_{1}\right)$ yaitu secara ad-libitum tidak berbeda nyata $(\mathrm{P}>0,05)$ dengan perlakuan pembatasan ransum $\mathrm{R}_{2}(85 \%)$, tetapi memberikan perbedaan nyata $(\mathrm{P}<0,05)$ dengan perlakuan R3 (70\%). Sedangkan perlakuan pembatasan ransum $\mathrm{R}_{2}(85 \%)$ tidak berbeda nyata dengan perlakuan $\mathrm{R}_{3}$ (70\%). Hal ini diduga karena bobot badan akhir ayam broiler hasil penelitian yang relatif sama, sehingga Income Over Feed Cost (IOFC) yang diperoleh relatif sama dari setiap perlakuan.

Tingginya Income Over Feed Cost pada $\mathrm{R}_{2}(\mathrm{Rp} .13,741 \pm 4.36)$ dan $\mathrm{R}_{3}(\mathrm{Rp}$ $\left.15,142^{\mathrm{a}} \pm 3.15\right)$ dari pada perlakuan pemberian $\mathrm{R}_{1}$ (Rp. 10,038 \pm 2.12 ), diduga ayam memanfaatkan ransum yang dikonsumsi untuk mencapai berat badan yang optimal dimana walaupun ransum yang dikonsumsi terbatas tetapi mampu mengkonversinya menjadi daging dengan menghasilkan bobot yang ideal sehingga memperoleh Income Over Feed Cost yang tinggi. Sedangkan antara perlakuan pembatasan ransum $\mathrm{R}_{1}(100 \%)$ dan $\mathrm{R}_{2}$ (85\%) yang memberikan hasil Income Over Feed Cost yang relative sama, diduga karena bobot badan akhir ayam broiler hasil penelitian yang relatif sama. Hal ini sesuai pendapat Rasyaf (2003) bahwa semakin efisien ayam dalam mengubah makanan menjadi daging yang artinya konversi ransumnya sangat baik, semakin baik pula Income Over Feed Cost-nya. Sedangkan pada perlakuan kepadatan kandang memberikan Income Over Feed Cost yang relatif sama. Menurut Rasyaf (2011), kepadatan kandang berpengaruh terhadap kenyamanan ternak di dalam kandang. Kepadatan kandang dapat mempengaruhi suhu dan kelembaban udara dalam kandang dan pada akhirnya akan mempengaruhi pertumbuhan ternak. Kepadatan kandang yang terlalu tinggi akan menyebabkan suhu dan kelembaban yang tinggi sehingga akan mengganggu fungsi fisiologis tubuh ayam (Guyton, 1997). Pengaruh secara langsung terutama terhadap fungsi beberapa organ dalam seperti jantung, alat pernafasan, dan manifestasi suhu tubuh.

\section{Kesimpulan}

Berdasarkan hasil penelitian dapat diambil beberapa kesimpulan antara lain :

1. Tidak terdapat interaksi antara faktor kepadatan kandang dengan faktor pembatasan ransum terhadap konsumsi ransum, 
pertambahan bobot badan, konversi ransum, persentase karkas, persentase lemak abdominal, ratio heterofil-limfosit (H/L) dan Income Over Feed Cost (IOFC) ayam broiler hasil penelitian.

2. Pada faktor kepadatan kandang, semakin padat kandang semakin menurunkan konsumsi ransum dan semakin rendah persentase lemak abdominal pada ayam broiler.

3. Pada faktor pembatasan ransum, semakin tinggi persentase pembatasan ransum semakin rendah ransum yang dikonsumsi dan semakin tinggi Income Over Feed Cost (semakin besar pendapatan usaha ayam broiler yang diperoleh).

4. Terjadi indikasi cekaman atau stres pada ayam broiler, tetapi masih menunjukkan performans produksi yang baik terhadap konsumsi ransum, pertambahan bobot badan, konversi ransum dan persentase karkas.

\section{Saran}

Dari hasil penelitian disarankan sebagai berikut :

1. Untuk meningkatkan efisiensi penggunaan ransum pada pemeliharaan ayam broiler, dapat dilakukan pemberian ransum sebanyak $70 \%$ dari standar kebutuhan.

2. Penempatan ayam dalam kandang dengan kepadatan sampai 7 ekor/ $0,5 \mathrm{~m}^{2}$ masih memberikan keuntungan secara ekonomis dan dapat dijadikan sebagai pertimbangan efisiensi tempat dan biaya penggunaan kandang untuk pemeliharaan ayam broiler.

\section{DAFTAR PUSTAKA}

Abubakar. 2003. Mutu karkas ayam hasil pemotongan tradisional dan penerapan sistem hazard analiysis critical control point. Jurnal Litbang Pertanian. Bogor, 22 (1): 33-39.

Al-Batshan, H.A. 2002. Performance and Heat Tolerance of Broilers as Affected by Genotype and High Ambient Temperature. AsianAust. J. Anim. Sci. 15 (10) : 15021506.

Al-Sultan, S. I. 2003. The effect of Curcuma longa (tumeric) on overall Performance of Broiler Chickens. International Journal of Poultry Science, 2 (5): 351-353

Al-Taleb, S.S. 2003. Effect of an Early Feed Restriction Productive Performance and Carcass Quality. J. Biol. Sci. 3: 607-611.

Amanda, Y. 2007. Performa Ayam Wereng Betina Fase Pertumbuhan pada Tingkat Kepadatan yang Berbeda. Skripsi. Fakultas Peternakan Institut Pertanian Bogor. Bogor.

Anggorodi, R. 1994. Ilmu Makanan Ternak Umum, Penerbit PT.Gramedia. Jakarta.

Azis, A., H. Abbas, Y. Heryandi dan E. Kusnadi. 2011. Pertumbuhan Kompensasi dan Efisiensi Produksi Ayam Broiler yang Mendapat Pembatasan Waktu Makan. Media Peternakan, April 2011, hlm. 50-57. EISSN 2087 4634 
Bell, D.D. 2002. Anatomy of The Chicken. In: Bell, D.D and W. D. Weaver Jr., Editor. Commercial Chicken Meat and Egg Production. Fifth edition. USA: Springer Science Business Media, Inc.

Colville T, and J. M. Bassert. 2008. Clinical Anatomy \& Physiology for Veterinary Technician. Missouri: Elsevier.

Cooper, M. A. and K. W. Washburn. 1998. The Relationship of Body Temperature to Weight Gain, Feed Consumption, and Feed Utilization in Broiler Under Heat Stress. Poultry Sci. 77 : 237-242.

Cunningham, J. G. 2002. Textbook of Veterinary Physiology. USA: Saunders Company.

Darmawati. 2005. Pemberian Pakan Terbatas secara Periodic pada Ayam Pedaging (Lenghorn). Jurnal Biogenesis Vol. 1(2): 4346, 2005.

Dozier, W. A., R. J. Lien, J. B. Hess, S. F. Bilgili, R. W. Gordon, C. P. Laster and S. L. Vieira. 2002. Effects of early skip-aday feed removal on broiler live performance and carcass yield. J. Appl. Poultry. Res. 11: 297-303.

Emadi, M. and H. Kermanshahi. 2007. Effect of turmeric rhizome powder on the activity of some blood enzymes in the broiler chickens. Int. J. Poult. Sci. 6: 48- 51.

Essay, L. O and L.E. Dawson. 1965. Quality of fryers carcass as related to protein and fat level in the diet fat deposition and moisture pick up during chilling. Poult. Sci. 44 : 7-11.

Gaman, P.M. 1992. Ilmu Pangan Pengantar Ilmu Pangan Nutrisi dan Mikrobiologi. Edisi Kedua. Gadjah Mada University Press. Yogyakarta.

Gaspersz, V. 1994. Teknik Analisis Dalam Penelitian Percobaan. Tarsito. Bandung.

Guyton dan Hall. 1997. Buku Ajar Fisiologi Kedokteran. Irawati Stiawan, penerjemah. Jakarta: EGC. Terjemahan dari: Textbook of Medical Physiology.

Haroen, U. 2003. Respon Ayam Broiler yang Diberi Tepung Daun Sengon (Albizzia falcataria) dalam Ransum terhadap Pertumbuhan dan Hasil Karkas. J. Ilmiah Ilmuilmu Peternakan. 6 (1): 34-41.

Heckert, R.A., I. Estevez, E.R. Cohen dan R.P.Riley.2002. Effects of density and perch availability on the immune status of broilers. Poult. Sci. 81:451-457.

Ingram, D.R., L.F. Hatten, and B.N. Mc. Pherson, 2000. Effects of light restriction on broiler performance and specific body structure measurements. J. Poult. Sci. 9 : 501-504.

Iskandar, S., Setyaningrum, Y. Amanda, dan I. Rahayu. 2009. Pengaruh Kepadatan Kandang terhadap Pertumbuhan dan Perilaku Ayam Wareng Tangerang. Balai Penelitian Ternak Ciawi. 14(1):1924. 
Jull, M.A. 1972. Poultry Husbandry. 3rd Ed, Tata McGraw-Hill Book Publishing Co. Ltd. New Delhi

Koswara.S.2009.PengolahanUnggashttp:/ /www.indabook.org/preview/peng olahan-unggas-teknologi-panganunimus.html. Diakses tanggal 27 Januari 2016.

Kusnadi, E. 2008. Pengaruh temperatur kandang terhadap konsumsi ransum dan komponen darah broiler. J. Indon. Trop. Anim. Agric, 33 (3) : 197-202.

Kusnadi, E. 2008. Perubahan malonaldehida hati, bobot relatif bursa fabricius dan rasio heterofil/limfosit $(\mathrm{H} / \mathrm{L})$ ayam Broiler yang diberi cekaman panas. Jurusan Produksi Ternak, Fakultas Peternakan, Universitas Andalas Padang, Padang

Matur, E., E. Ergul, I. Akyazi, E. Eraslan, and Z. T. Cirakli. 2010. The effects of Saccharomyces cerevisiae extract on the weight of some organs, liver, and pancreatic digestive enzyme activity in breeder hen fed diets contaminated with alfatoxins. Poult. Sci. 89:2213-2220.

May, J. D and B. D. Lott. 2000. The Effect of Environmental temperature on growth and feed conversion of broiler to 21 days of age. Poult. Sci, 79: $669-671$.

Olanrewaju, H. A., J. L. Purswell, S.D. Collier and S.L. Branton. 2010. Effect of ambient temperature and light intensity on growth performance and carcass characteristics of heavy broiler chickens at 56 days of age. Int. J. of Poult. Sci. 9(8): 720-725.

Maynard,L.A., J.K.Loosli, H.F. Hinta and R.G. Warner,1979, Animal Nutrition, 7Ed.Tata -Mc. Graw Hill, Publishing Company Limited, New Delhi.

North, M. O. and D. D. Bell. 1990. Commercial Chicken Production Manual. 4th edn. Van Northland Reinhold, New York.

Rasyaf, M. 2007. Manajemen Peternakan Ayam. Penebar Swadaya. Jakarta

Santoso, U. 2001. Pengaruh Pemberian Kultur Bacillus Subtilis Selama Periode Refeeding terhadap Performans dan Komposisi Kimia Karkas. Med. Vet. 7:17-19.

Setiawan, I dan E. Sujana. 2009. Bobot akhir, persentase karkas dan lemak abdominal ayam broiler yang dipanen pada umur yang berbeda. seminar nasional fakultas peternakan unpad "Pengembangan Sistem Produksi dan Pemanfaatan Sumberdaya Lokal untuk Kemandirian Pangan Asal Ternak". Bandung. ISBN : $978-602-95808$ $-0-8$.

STEEL, R.G.D. and J.H. TORRIE. 1993. Prinsip dan Prosedur Statistik Suatu Pendekatan Biometrik. Principles and Procedures of Statistics, Terjemahan SUMANTRI, B. Cetakan ke-3, PT Gramedia, Jakarta.

Sturkie, P. D. 1976. Avian Physiology Third Edition. Springer Verlag. New York.

Tillman. A.D, dkk. 1984. Ilmu Pakan Ternak Dasar Penerbit Gadjah Mada University Press Yogyakarta. 
Uzer, F., N. Iriyanti dan Roesdiyanto. 2013. Penggunaan pakan fungsional dalam ransum ter-hadap konsumsi pakan dan pertambahan bobot badan ayam broiler. J. Ilmiah Peter-nakan. 1 (1): 282-288.

Widjakusuma, R., dan S.H.S Sikar, 1986. Fisiologi Hewan. Institut Pertanian Bogor, Press, Bogor

Yamin, M. 2008. Pemanfaatkan Ampas Kelapa dan Ampas Kelapa Fermentasi dalam Ransum terhadap Efesiensi Ransum dan Income Over Feed Cost Ayam Pedaging. J. Agroland. 15 (2): 135 -139.

Yuniastuti, A., 2002. Efek Pakan Berserat pada Ransum Ayam terhadap Kadar Lemak dan Kolesterol Daging Broiler. JITV, 9 (3) : 175 - 183.

Zahra, T. 1996. Pengaruh Tinggak Penggunaan Protein dan Kepadatan Kandang Terhadap Performans Ayam Ras Petelur pada Fase Produksi. Skripsi Fakultas Peternakan Universitas Andalas. Padang. 